$\S=-1$

\title{
A Study on Employer Branding Dimensions in Selected IT Firms
}

\author{
S. Bharath ${ }^{1 *}$, P. Nagesh ${ }^{2}$ \\ ${ }^{1}$ JSS Centre for Management Studies \\ Sri Jayachamarajendra College of Engineering, Mysore - 570 006, Karnataka, India \\ ${ }^{2}$ JSS Centre for Management Studies \\ Sri Jayachamarajendra College of Engineering, Mysore - 570 006, Karnataka, India \\ *Corresponding author E-mail:sindu.koppa@gmail.com
}

\begin{abstract}
The factors associated with branding were identified beneath communication/marketing remit. There existed no difference between the employer brand and consumer brand. Companies who had strong product/ service brand would de facto be attractive to potential employees. Today, companies require blended capabilities. Ultimately, it is the personal experience of the relationship that a person develops within an organization that determines the longevity and win-win consummation of association. An extended concept of relationship marketing principle is Employer branding. An endeavor has been made through this research with an objective to identify the Employer Branding Dimensions (EBD) in selected Information technology firms located in Bangalore from existing employee perspective. Study has been executed using structured questionnaire with Information Technology (IT) employees as respondents from various companies like, Infosys, IBM, NTT DATA, Marvell technologies, JDA software solutions. Data thus collected is analysed using software package and considering the factor loadings, key dimensions (factors) that constituted the Employer branding. The findings of the study emphasize that relationship among dimensions constituting individual employer branding highlights the complexity in its significance as no individual factor has dominant influence on Employer Branding. But many factors in combination acts on branding.
\end{abstract}

Key Words: Employer Branding; Information Technology; Dimensions

\section{Introduction}

Highly prolific period of employees' life is spent in the organization. Employees emanate the values and culture of the organization they work and outsiders will typically compare and contrast the information received from them. When employer is viewed constructively by employees and by others, organization affiliation enhances one's self-esteem and organization identification is expected to be strong. The reverse happens when the employer is held in low regard.

Definitely the spot light on employer branding has enhanced over the previous few years. Globalization and occurrence of service economies have augmented the demand for skilled and talented workforce. Companies across the globe are developing their image through systematic application of marketing principles to recruit and retain employees.

The global financial crises of 2008-2010, has an impact on aspects of economic life, resulting in cost cutting across the board. In times of financial and economic distress it is the best talents which will help the organization to strive through and sustain performance.

Johnson \& Roberts $(2006)^{1}$ cited a study that indicates $40 \%$ of job seekers ranked treatment of employers highest in their perception of organization and place to work while $29 \%$ ranked quality of products or service as most important factor.

Research by the Charted Institution of Personnel and Development (CIPD) shows that approximately $75 \%$ of companies that use employer branding as a tool for recruitment and selection which is most effective. (Dyar, 2007) ${ }^{2}$. Bryan $(2007)^{3}$ advocates that gaug- ing corporate performance through financial index alone (balance sheets, cash flows, ROIC) does not really replicate actual wealth.

\section{Employer Branding}

Ambler and Barrow (1996) ${ }^{4}$ defined employer brand in terms of benefit, calling it "The package of functional, economical and psychological benefit provided by employment and identification with the employing company".

In simple promote within and terms, employer branding is referred to as a firm's effort to outside the firm, a clear view of the fact that makes it different and desirable as an employer.

Thus, building brand is all about the marketing of "employment" if employee is considered as "customers" and "employment experience" as a "product" being offered for their consideration and purchase the "customer Satisfaction" would then reflect the strength of the "Employment Brand" of the organisation. (Tikoo $2004)^{5}$

\section{Literature Review}

Regardless of employer brand seeking noteworthy fame in Human Resource area (Frook 2001) ${ }^{6}$. The employer brand concept has been recent in academics and its hypothetical foundation is to be enhanced progressively.

Existing literature can be reviewed from two broad perspectives

(1) Prospective employee's perspective

(2) Existing employee perspective 
Racha and Knox (2009) ${ }^{7}$ made a study to understand what motivates current employees to "experience the brand". The study has answered the question through the lens of Social Identity Theory (SIT) conducting a comparative case study across five organizations and found that the definite characteristics considered most attractive by employer were different in each organization. It is also noted that managers need to identify the attributes of their own organization so that employees shall find most attractiveness within the categories to link the employer brand with the individuality of the organization.

Linda F. Love \& Prabudayal Singh $(2011)^{8}$ outlines in their research that workplace branding uses a similar approach used in marketing a product or service to build effective internal brand. The researchers use popular annual "Best Employer "surveys to identify key human resource image creators like Canada's topmost 100 employers, 50 Paramount Employers in Canada, Canada's most well-regarded corporate cultures, Fortune 100 Best corporations to work for in America. Eight common themes are identified. Pushpendra Priyadarshi $(2011)^{9}$ had attempted to understand Employer Brand Image (EBI) of an organization from current employees view point to comprehend the nature of relation between $\mathrm{EBI}$ and job satisfaction, affections, commitment of the employees. sample of 240 professional drawn from telecom sector in NCR Delhi. They used EBI instrument designed by Knox and freeman $(2006)^{10}$ An exploratory factor analysis of these work recognized numerous dimensions of EBI and they are classified into four broad factors i.e. Organizational environment, Organization fame and flexibility, Varity in job and work setting Composition and career. The study provided critical inputs about internal images and its influence on job related attitude.

Robertson and Khatibi (2012) ${ }^{11}$ has conducted a study attempts to provide an insight into the interaction of organisational images through carefully designed employer branding process which produces employer brand. Information was gathered from a Srilankan companies using structured questionnaire with sample of $303 \mathrm{em}-$ ployee. To address the objective, framework is developed to find relationship between Employee Value propositions (EVP) and source Identities. Indications were EVP has a significant role in the development of the employer brand, but to be effective it must meticulously have aligned with other connected identities.

Kanika and Malati (2013) $)^{12}$ has contributed to the field by conducting a comparative analysis of the employee perspective towards the branding practices embraced. Data was collected administering convenient sampling for a total of 120 employees from various hotel including ITC, The Oberoi and the Hotel Leela in Delhi, NCR region. Through the data analysis the authors interpreted that the employer branding practices which are prevalent at hotel ITC need to be incorporated by hotel Oberoi and Hotel Leela are use of 'social media', corporate social responsibility and also, association with a celebrity to increase their visibility and create good brand image. According the study ITC hotel is significantly different as compared to other two hotels in context of the branding practices, whereas hotel Oberoi and hotel Leela are alike.

Neha Sharma And T.J Kamalanabhan (2014) ${ }^{13}$ attempts to study the internal corporate communication (ICC) process, investigating the nature of the procedure, the outcomes thereof; The authors have attempted to develop a measure that can capture all the dimensions of ICC and takes an ICC-based perspective in understanding internal branding of IT service firms, technological channels employee feedback etc. current study suggests that ICC does matter in practice and its relation with internal branding outcomes can be beneficial for organisations particularly service organizations to optimize resources.

Nor Adibah Ahmada and Salina Daud (2016) ${ }^{16}$ aims to determine the relationship between Employer Branding and Turnover Intention among employees in Malaysia's SME-ICT Industry. A cross sectional study and quantitative research methods were used in the study. Authors concludes that it is essential not only for branding the organization and capturing employee's loyalty, but also for ensuring the efficiency of employees.
Existing literatures have clearly indicated that there is a strong need to study the Employer Branding Practices in service sector from existing employee perspective.

Janse \& Roott $(2009)^{14}$ has stressed on the gap that exist between recruitment's focus and expectations of company.

Neethi et.al $(2008)^{15}$ observe that in today's corporate world, recruitment seems to be the top priority of many HR practitioners, though utmost focus should be given on retention as ' getting them is tough but keeping them glued is tougher". They identify that more studies should be undertaken from the current employees' perspective.

The proposed study focuses on addressing the above said gap and attempts to study the Employer branding dimensions from Existing employees' perspective.

\section{Research Design}

\subsection{Objectives}

The objective of the present research is two-fold

a. To identify the Employer Branding Dimensions (EBD)

b. To understand the relationship among Dimensions of Employer Branding.

\subsection{Scope}

The scope of the study extends to select IT Companies based in Bangalore.

\subsection{Sampling and Data Collection}

Statistically, it is desired to have the standard error not more than $10 \%$ and $90 \%$ of confidence level is considered to determine the size.

$\mathrm{N}=\mathrm{Z} 2[\pi(1-\pi)] / \mathrm{E} 2$

Where,

$\mathrm{N}=$ Sample size to be determined

$\pi=$ the proportion of sample considered

$\mathrm{Z}=$ the confidence coefficient $(1.96$ for $95 \%$ )

Accordingly, $\mathrm{N}=\mathrm{Z}^{2}[\pi(1-\pi)] / \mathrm{E}^{2}=(1.96)^{2}[0.15 \mathrm{X} 0.85] /$

$[0.085]^{2}=67.8$.

Therefore, sample is considered as 68 .

The primary data is collected from the fieldwork. The objective of the study is briefed to all the respondents before the survey. The data, thus collected is classified based on homogeneous factors and tabulated to enable for the statistical analysis. Data was gathered using Self-administered questionnaires from the personnel working in Information Technology firms in Bangalore. Total of 68 filled in questionnaires were used for further analysis.

Employees of well recognized IT companies like Infosys, NTT data, JDA Software solutions, Marvell Technologies were selected for the study.

\subsection{Hypothesis}

The Hypothesis thus formulated for the present research is as follows

H1: Set of hypotheses is formulated to know the significance difference between Reward \& Recognition and other dimensions like open environment, Employee empowerment, Service \& support, Job characteristics and Career advancement opportunities

$\mathrm{H} 2$ : Second Set of hypotheses is formulated to know the significance difference between open environment and other dimensions like Reward\& Recognition, Employee empowerment, Service \&support, Job characteristics and Career advancement opportunities

H3: Third Set of hypotheses is formulated to know the significance difference between Employee empowerment and other dimensions like Reward \& Recognition, open environment, Service 
\& support, Job characteristics and Career advancement opportunities

H4: Forth Set of hypotheses is formulated to know the significance difference between Service \& support and other dimensions like Reward \& Recognition, open environment, Employee empowerment, Job characteristics and Career opportunities.

H5: Fifth Set of hypotheses is formulated to know the significance difference between Job characteristics and other dimensions like Reward \& Recognition, open environment, Employee empowerment, Service \& support and Career advancement opportunities

H6: Final Set of hypotheses is formulated to know the significance difference between Career advancement opportunities and other dimensions like Reward \& Recognition, open environment, Employee empowerment, Service \& support and Job characteristics.

\section{Data Analysis and Result}

Data was analysed in two stages. In the first stage Expert interview has been conducted to know the prevailing practices in Information Technology (IT) firms which formed the basis for formulating questionnaire.

Table 1: Descriptive Statistics

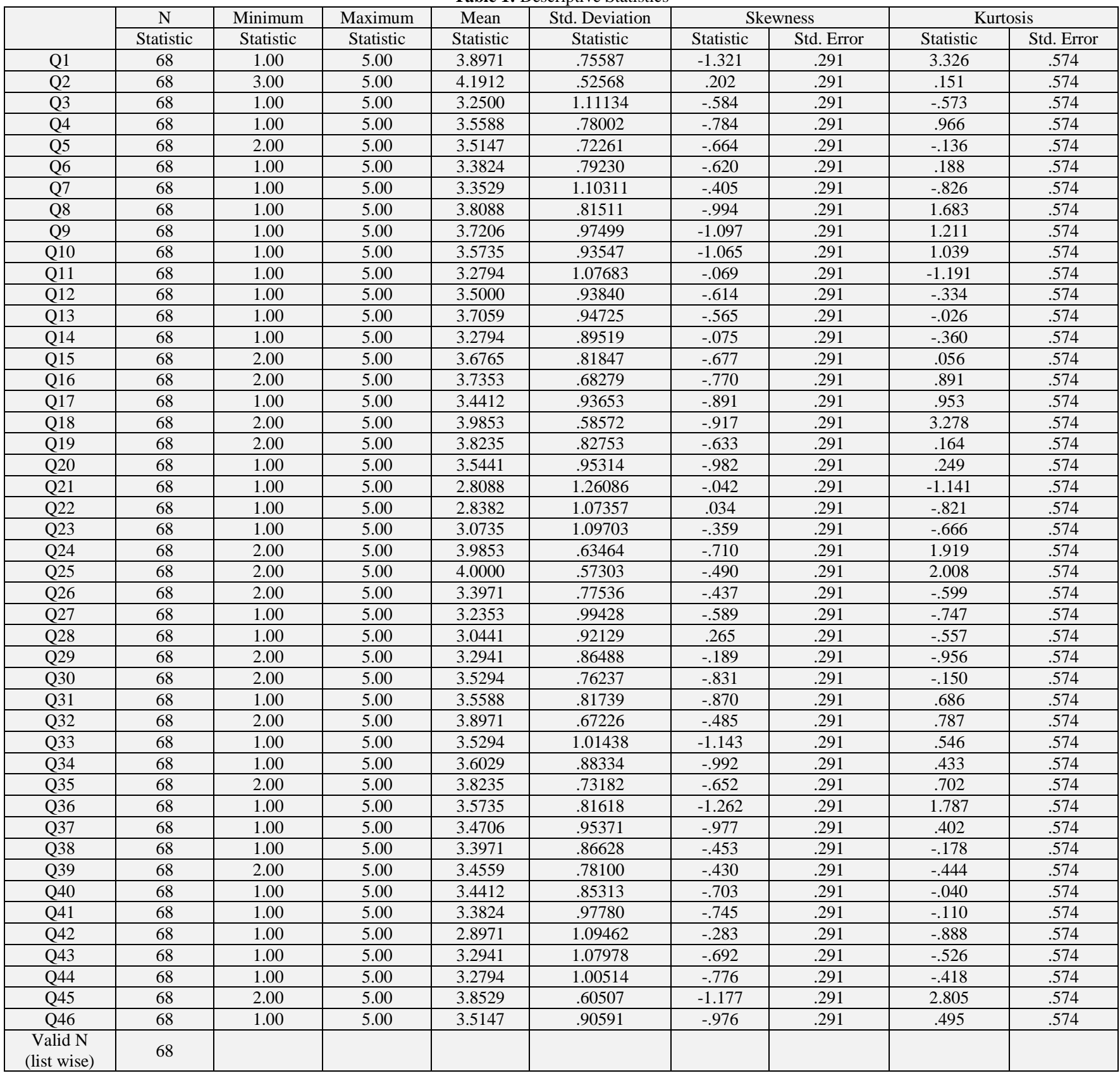

In the next phase, based on the review and objectives structured questionnaire has been advanced and pilot study is conceded among 20 employees, subsequently considering and incorporating the modifications final questionnaire was circulated for data collection.

Descriptive data are illustrated in table1.The exploratory factor analysis is done and the results of factor analysis are shown in Table 4, As can be seen, 29 variables in the scale were factored using principal component analysis with varimax rotation these six dimensions (Ref Table 5) were extracted accounting for $75 \%$ of total variance (refer Table 3). Factor loadings greater than or equal to 0.5 is considered for further analysis. Reliability factors are calculated using Cronbach's alpha (ref Table 6). Alpha value of 0.7 and more have been considered to be acceptable for the factor to be reliable, accordingly only six out of nine factors have 
satisfactory value of Cronbach's alpha. Hence those six factors are reliable and considered for further study.

Table 2: KMO and Bartlett's Test

Kaiser-Meyer-Olkin Measure of Sampling Adequacy.

\begin{tabular}{|l|l|r|}
\hline \multirow{2}{*}{ Bartlett's Test of Sphericity } & Approx. Chi-Square & .75 \\
\cline { 2 - 4 } & Df & 1660.811 \\
\cline { 2 - 3 } & Sig. & .000 \\
\hline
\end{tabular}

Table 3: Total variance explained

\begin{tabular}{|c|c|c|c|c|c|c|}
\hline \multirow{2}{*}{ 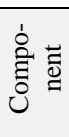 } & \multicolumn{3}{|c|}{ Initial Eigenvalues } & \multicolumn{3}{|c|}{$\begin{array}{c}\text { Extraction Sums of Squared } \\
\text { Loadings }\end{array}$} \\
\hline & Total & \begin{tabular}{|c|}
$\%$ of \\
Variance \\
\end{tabular} & Cumulative \% & Total & \begin{tabular}{|c|}
$\%$ of \\
Variance \\
\end{tabular} & Cumulative ? \\
\hline \begin{tabular}{|l|}
1 \\
\end{tabular} & 12.533 & \begin{tabular}{|l|}
35.809 \\
\end{tabular} & 35.809 & 12.533 & \begin{tabular}{|l|}
35.809 \\
\end{tabular} & 35.809 \\
\hline 2 & 2.626 & 7.502 & 43.310 & 2.626 & 7.502 & 43.310 \\
\hline 3 & 2.225 & 6.357 & 49.668 & 2.225 & 6.357 & 49.668 \\
\hline 4 & 2.012 & 5.749 & 55.417 & 2.012 & 5.749 & 55.417 \\
\hline 5 & 1.634 & 4.667 & 60.084 & 1.634 & 4.667 & 60.084 \\
\hline 6 & 1.481 & 4.232 & 64.317 & 1.481 & 4.232 & 64.317 \\
\hline 7 & 1.399 & 3.997 & 68.314 & 1.399 & 3.997 & 68.314 \\
\hline \begin{tabular}{|l|}
8 \\
\end{tabular} & 1.234 & 3.526 & \begin{tabular}{|l|}
71.840 \\
\end{tabular} & 1.234 & 3.526 & \begin{tabular}{|l|}
71.840 \\
\end{tabular} \\
\hline 9 & 1.090 & 3.115 & 74.955 & 1.090 & 3.115 & 74.955 \\
\hline 10 & .961 & 2.746 & 77.701 & & & \\
\hline 11 & .855 & 2.443 & 80.144 & & & \\
\hline 12 & .735 & 2.100 & 82.244 & & & \\
\hline 13 & .673 & 1.924 & 84.168 & & & \\
\hline 14 & .660 & 1.884 & 86.052 & & & \\
\hline 15 & .529 & 1.513 & \begin{tabular}{|l|}
87.565 \\
\end{tabular} & & & \\
\hline 16 & .451 & 1.289 & 88.854 & & & \\
\hline 17 & .427 & 1.221 & 90.075 & & & \\
\hline 18 & .417 & 1.191 & 91.266 & & & \\
\hline 19 & .398 & 1.138 & \begin{tabular}{|l|}
92.404 \\
\end{tabular} & & & \\
\hline 20 & .360 & 1.029 & 93.433 & & & \\
\hline 21 & .285 & .814 & 94.246 & & & \\
\hline 22 & .268 & .767 & 95.013 & & & \\
\hline 23 & .251 & .718 & 95.731 & & & \\
\hline 24 & .224 & .639 & 96.370 & & & \\
\hline 25 & .213 & .609 & 96.979 & & & \\
\hline 26 & .173 & .493 & 97.473 & & & \\
\hline 27 & .166 & .475 & 97.947 & & & \\
\hline 28 & .149 & .425 & 98.372 & & & \\
\hline 29 & .129 & .368 & 98.740 & & & \\
\hline 30 & .111 & .318 & 99.058 & & & \\
\hline 31 & .087 & .250 & 99.308 & & & \\
\hline 32 & .086 & .247 & 99.555 & & & \\
\hline 33 & .064 & .184 & \begin{tabular}{|l|}
99.739 \\
\end{tabular} & & & \\
\hline 34 & .057 & .164 & 99.903 & & & \\
\hline 35 & .034 & 7 & 0. & & & \\
\hline
\end{tabular}

Table 4: Rotated Factor Matrix

\begin{tabular}{|c|c|c|}
\hline Dimensions & Item Constructs & $\begin{array}{c}\text { Factor } \\
\text { loadings }\end{array}$ \\
\hline \multirow{10}{*}{ Dimension 1} & Employee benefits & 0.784 \\
\hline & Goals of organization & 0.528 \\
\hline & Performance based compensation & 0.806 \\
\hline & Compensation system & 0.772 \\
\hline & Adequate salary & 0.703 \\
\hline & Reward for additional work & 0.674 \\
\hline & Policies and procedures & 0.630 \\
\hline & Healthy work environment & 0.595 \\
\hline & proud to associate with this organization & 0.571 \\
\hline & competent people & 0.565 \\
\hline \multirow[t]{5}{*}{ Dimension 2} & Concerns are addressed & 0.617 \\
\hline & Feedback on regular basis & 0.715 \\
\hline & HR practices meet personal needs & 0.698 \\
\hline & HR practices meet professional needs & 0.824 \\
\hline & Flexible working conditions. & 0.597 \\
\hline \multirow[t]{4}{*}{ Dimension 3} & Empowered to initiate in this organization & 0.722 \\
\hline & The client/customer are satisfied & 0.660 \\
\hline & Management welcomes opinions & 0.607 \\
\hline & $\begin{array}{l}\text { Accepts new ideas and provides support to } \\
\text { try those. }\end{array}$ & 0.710 \\
\hline Dimension 4 & Stress free work environment & 0.779 \\
\hline
\end{tabular}

\begin{tabular}{|c|c|c|}
\hline & Organisation culture & 0.672 \\
\hline & $\begin{array}{l}\text { Trust my superiors when they suggest any } \\
\text { action plan. }\end{array}$ & 0.516 \\
\hline & Work life balance & 0.648 \\
\hline \multirow[t]{3}{*}{ Dimension 5} & $\begin{array}{l}\text { satisfied with my performance in the pro- } \\
\text { cess }\end{array}$ & 0.711 \\
\hline & Job satisfaction & 0.677 \\
\hline & Role/job content is very interesting & 0.714 \\
\hline \multirow[t]{3}{*}{ Dimension 6} & Opportunities for international travel & 0.814 \\
\hline & $\begin{array}{l}\text { Opportunities for long term progression in } \\
\text { the company }\end{array}$ & 0.547 \\
\hline & Responsibilities matches my potential & 0.778 \\
\hline
\end{tabular}

Table 5: Rotated Component Matrix

\begin{tabular}{|c|c|c|c|c|c|c|}
\hline & & & Col & nent & & \\
\hline & 1 & 2 & 3 & 4 & 5 & 6 \\
\hline \begin{tabular}{|l|} 
Q23 \\
\end{tabular} & .806 & & & & & \\
\hline Q3 & .784 & & & & & \\
\hline Q42 & .772 & & & & & \\
\hline \begin{tabular}{|l|} 
Q21 \\
\end{tabular} & .703 & & & & & \\
\hline Q22 & .674 & & & & & \\
\hline Q36 & .630 & & & & & \\
\hline Q15 & .595 & & & & & \\
\hline Q8 & .571 & & & & & \\
\hline Q4 & .565 & & & & & \\
\hline Q1 & .528 & & & & & \\
\hline Q29 & & .824 & & & & \\
\hline Q27 & & .715 & & & & \\
\hline Q28 & & .698 & & & & \\
\hline Q26 & & .617 & & & & \\
\hline Q19 & & .597 & & & & \\
\hline Q5 & & & .722 & & & \\
\hline \begin{tabular}{|l|} 
Q39 \\
\end{tabular} & & & .710 & & & \\
\hline Q2 & & & 660 & & & \\
\hline Q38 & & & .607 & & & \\
\hline Q7 & & & & .779 & & \\
\hline Q43 & & & & .672 & & \\
\hline Q20 & & & & .648 & & \\
\hline \begin{tabular}{|l|} 
Q46 \\
\end{tabular} & & & & .516 & & \\
\hline \begin{tabular}{|l} 
Q34 \\
\end{tabular} & & & & & .714 & \\
\hline Q32 & & & & & .711 & \\
\hline Q33 & & & & & .677 & \\
\hline Q9 & & & & & & .814 \\
\hline Q37 & & & & & & .778 \\
\hline Q14 & & & & & & .547 \\
\hline
\end{tabular}

Table 6: Reliability Statistics

\begin{tabular}{|c|c|c|}
\hline \multicolumn{3}{|c|}{ Table 6: Reliability Statistics } \\
\hline Factors & Cronbach's Alpha & N of Items \\
\hline 1 & .916 & 10 \\
\hline 2 & .862 & 5 \\
\hline 3 & .835 & 4 \\
\hline 4 & .798 & 4 \\
\hline 5 & .767 & 3 \\
\hline 6 & .775 & 3 \\
\hline
\end{tabular}

\subsection{Dimension Labeling and Interpretation}

The dimensions obtained from the analysis are labelled under the following heads

Dimension 1: Rewards and Recognition.

Dimension 2: Open Environment.

Dimension 3: Empowerment.

Dimension 4: Service and Support

Dimension 5: Job Characteristics.

Dimension 6: Career Advancement Opportunities.

D1: Rewards and Recognition:

The dimension accounted for around $36 \%$ of the variance described. It assessed the extent to which an employee considers to be meaningful to associate himself with his organization which 
conveys company's value proposition in terms of adequate salary, benefits, incentives based on performance.

D2: Open Environment:

The dimension accounted for about $8 \%$ of the variance explained. It assessed the extent to which an employee considers to be meaningful to associate himself with his organization which conveys company's value proposition in terms of Exciting work environment, Employee friendly working condition.

D3: Employee Empowerment:

The dimension accounted for about $6 \%$ of the variance explained. It assessed the extent to which an employee considers to be meaningful to associate himself with his organization which conveys company's value proposition in terms of Initiative spirit of employees, Opportunity for experimenting new ideas.

D4: Service and Support:

The dimension accounted for about $6 \%$ of the variance explained. It assessed the extent to which an employee considers to be meaningful to associate himself with his organization which conveys company's value proposition in terms of stress free Work, cordial superior-subordinate relationship, trustworthy co-workers, opportunity to balance work life.

D5: Job Characteristics:

With about $5 \%$ of the variance elucidated. It assessed the extent to which an employee considers to be meaningful to associate himself with his organization which conveys company's value proposition in terms of performance oriented job process, Interesting role/job content.

D6: Career Advancement Opportunities:

The dimension accounted for about $4 \%$ of the variance explained It assessed the extent to which an employee considers to be meaningful to associate himself with his organization which conveys company's value proposition in terms of performance oriented job process, Interesting role/job content.

Table 7: Combined Mean and Standard deviation for EBD

\begin{tabular}{|l|c|c|}
\hline \multicolumn{1}{|c|}{ Dimensions } & Mean & Standard Deviation \\
\hline Rewards \& Recognition(X1) & 0.338 & 1.026 \\
\hline Open Environment(X2) & 0.359 & 0.912 \\
\hline Employee Empowerment(X3) & 0.640 & 0.797 \\
\hline Service \& Support(X4) & 0.426 & 1.012 \\
\hline Job Characteristics(X5) & 0.676 & 0.876 \\
\hline Career Advancement Opportunities(X6) & 0.490 & 0.952 \\
\hline
\end{tabular}

\subsection{Framework}

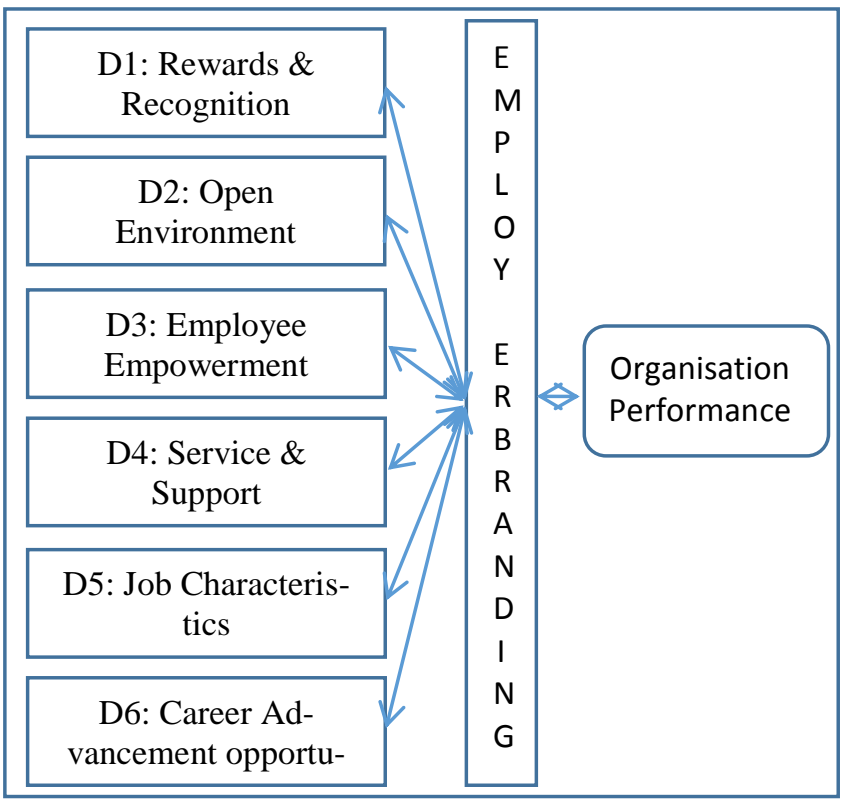

Fig. 1: The framework of the present research

\section{Interrelationship among Constructs}

The diagram below depicts the interrelationship among identified dimension of EBD that exists in IT firms.

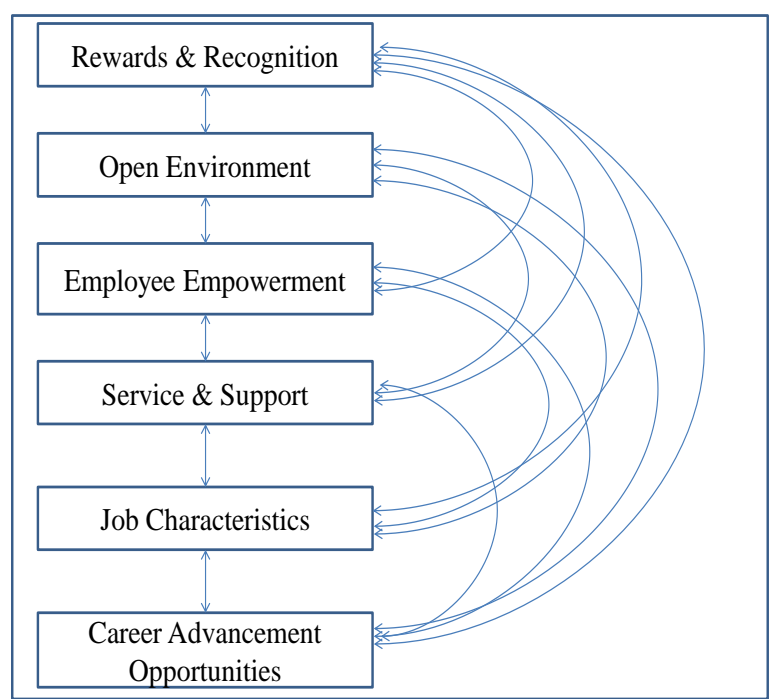

Fig. 2: Interrelationship among constructs (Refer table 8 for $\mathrm{Z}$ score)

\section{Results and Inference}

The objective of this research paper is to identify the dimensions that constitute Employer Branding.

The results from table 8 shows that there is no significant relationship between reward and recognition and open environment, service \& support \& career advancement opportunities while rejecting null hypothesis proves that there is relationship is significant between reward and recognition and, Employee Empowerment, Job characteristics. It is incidental from hypothesis testing that there exists relationship between open environment to employee empowerment and job characteristics.

Analysing the third dimension, it can be noted that no relationship exists between Employee empowerment to job characteristics, service and support and career advancement opportunities. While it can be stated that there is relationship between Employee Empowerment, reward\& recognition and open environment. There exists no significant relationship between service \&Support to either of the other dimensions like rewards \& recognition, Open environment, Employee Empowerment, Job Characteristics and career advancement Opportunities.

While analysing the relationship between job characteristics and other dimensions, it shows that there is significant relationship with rewards \& recognition and open environment. The relationship with Employee Empowerment, service and support and career advancement opportunities are negative.

\section{Conclusion}

As strategy used to retain existing employees are controllable by employer. The outcomes of this paper help organizations develop Human resource strategies with right blend of EBD to keep employees glued \& progressive to the organization. Specifically, in IT Sector, where there are infinite opportunities and less employee loyalty which has created an environment where the business needs its employees supplementary than employees need the industry. 
Table 8: Results of Hypothesis Testing

\begin{tabular}{|c|c|c|c|c|}
\hline Null Hypothesis (H0) & $\begin{array}{c}\mathbf{Z} \\
\text { Value }\end{array}$ & $\begin{array}{c}\text { Criti- } \\
\text { cal } \\
\text { value }\end{array}$ & $\begin{array}{c}\text { Confi- } \\
\text { dence } \\
\text { level }\end{array}$ & Decision \\
\hline $\begin{array}{l}\text { H1: There is no significance relationship between Rewards \& Recognition and Organization Environ- } \\
\text { ment }\end{array}$ & $\overline{-} \overline{124}$ & 1.64 & $90 \%$ & $\begin{array}{l}\text { Accepted } \\
\mathrm{H}_{0}\end{array}$ \\
\hline $\begin{array}{l}\text { H2: There is no significance relationship between Rewards \& Recognition and Employee Empower- } \\
\text { ment }\end{array}$ & $\begin{array}{c}- \\
1.899\end{array}$ & 1.64 & $90 \%$ & $\begin{array}{c}\text { Rejected } \\
\mathrm{H}_{0}\end{array}$ \\
\hline H3: There is no significance relationship between Rewards \& & $\overline{-}-\overline{502}$ & 1.64 & $90 \%$ & $\begin{array}{c}\text { Accepted } \\
\mathrm{H}_{0}\end{array}$ \\
\hline H4: There is no significance relationship between Rewards \& Recognition and Job Characteristics & $-\overline{1}-5$ & 1.64 & $90 \%$ & $\begin{array}{c}\text { Rejected } \\
\mathrm{H}_{0}\end{array}$ \\
\hline $\begin{array}{l}\text { H5: There is no significance relationship between Rewards \& Recognition and Career Advancement } \\
\text { opportunities }\end{array}$ & - & 1.64 & $90 \%$ & $\begin{array}{l}\text { Accepted } \\
\mathrm{H}_{0}\end{array}$ \\
\hline H6: There is no significance relationship between Open Environment and Reward \& Recognition & 0.124 & 1.64 & $90 \%$ & $\begin{array}{c}\text { Accepted } \\
\mathrm{H}_{0}\end{array}$ \\
\hline $\begin{array}{l}\text { H7: There is no significance relationship between Open } \\
\text { Environment and Employee Empowerment }\end{array}$ & $\begin{array}{c}- \\
1.915 \\
\end{array}$ & 1.64 & $90 \%$ & $\begin{array}{c}\text { Rejected } \\
\mathrm{H}_{0}\end{array}$ \\
\hline H8: There is no significance relationship between Open Environment and Service \& Support & $0 . \overline{407}$ & 1.64 & $90 \%$ & $\begin{array}{c}\text { Accepted } \\
\mathrm{H}_{0}\end{array}$ \\
\hline H9: There is no significance relationship between Open Environment and Job Characteristics & 2.069 & 1.64 & $90 \%$ & $\begin{array}{c}\text { Rejected } \\
\mathrm{H}_{0}\end{array}$ \\
\hline $\begin{array}{l}\text { H10: There is no significance relationship between Open Environment and Career Advancement Oppor- } \\
\text { tunities }\end{array}$ & $\overline{0}-\overline{821}$ & 1.64 & $90 \%$ & $\begin{array}{l}\text { Accepted } \\
\mathrm{H}_{0}\end{array}$ \\
\hline $\begin{array}{l}\text { H11: There is no significance relationship between Employee Empowerment and Reward \& Recogni- } \\
\text { tion }\end{array}$ & 1.917 & 1.64 & $90 \%$ & $\begin{array}{c}\text { Rejected } \\
\mathrm{H}_{0}\end{array}$ \\
\hline H12: There is no significance relationship between Employee Empowerment and Open Environment & 1.915 & 1.64 & $90 \%$ & $\begin{array}{c}\text { Rejected } \\
\mathrm{H}_{0}\end{array}$ \\
\hline H13: There is no significance relationship between Employee Empowerment and Service \& Support & 1.37 & 1.64 & $90 \%$ & $\begin{array}{l}\text { Accepted } \\
\mathrm{H}_{0}\end{array}$ \\
\hline H14: There is no significance relationship between Employee Empowerment and Job Characteristics & $-\overline{251}$ & 1.64 & $90 \%$ & $\begin{array}{c}\text { Accepted } \\
\mathrm{H}_{0}\end{array}$ \\
\hline $\begin{array}{l}\text { H15: There is no significance relationship between Employee Empowerment and Career Advancement } \\
\text { Opportunities }\end{array}$ & 0.996 & 1.64 & $90 \%$ & $\begin{array}{l}\text { Accepted } \\
\mathrm{H}_{0}\end{array}$ \\
\hline H16: There is no significance relationship between Service \& Support and Rewards \& Recognition & 0.504 & 1.64 & $90 \%$ & $\begin{array}{l}\text { Accepted } \\
\mathrm{H}_{0}\end{array}$ \\
\hline H18: There is no significance relationship between Service \& Support and Employee Empowe & -1.37 & 1.64 & $90 \%$ & $\begin{array}{c}\text { Accepted } \\
\mathrm{H}_{0}\end{array}$ \\
\hline H19: There is no significance relationship between Service \& Support and Job characteristics & -1.54 & 1.64 & $90 \%$ & $\begin{array}{c}\text { Accepted } \\
\mathrm{H}_{0}\end{array}$ \\
\hline $\begin{array}{l}\text { H20: There is no significance relationship between Service \& Support and Career Advancement Oppor- } \\
\text { tunities }\end{array}$ & -0.38 & 1.64 & $90 \%$ & $\begin{array}{l}\text { Accepted } \\
\mathrm{H}_{0}\end{array}$ \\
\hline H21: There is no significance relationship between Job Characteristics and Rewards \& Recognition. & 2.066 & 1.64 & $90 \%$ & $\begin{array}{c}\text { Rejected } \\
\mathrm{H}_{0}\end{array}$ \\
\hline H22: There is no significance relationship between Job Characteristics and Open Environment. & 2.069 & 1.64 & $90 \%$ & $\begin{array}{c}\text { Rejected } \\
\mathrm{H}_{0}\end{array}$ \\
\hline H23: There is no significance relationship between Job Characteristics and Employee Empowe & 0.251 & 1.64 & $90 \%$ & $\begin{array}{l}\text { Accepted } \\
\mathrm{H}_{0}\end{array}$ \\
\hline H24: There is no significance relationship between Job Characteristics and Service and support & 1.54 & 1.64 & $90 \%$ & $\begin{array}{l}\text { Accepted } \\
\mathrm{H}_{0}\end{array}$ \\
\hline $\begin{array}{l}\text { H25 There is no significance relationship between Job Characteristics and Career Advancement Oppor- } \\
\text { tunities }\end{array}$ & 1.186 & 1.64 & $90 \%$ & $\begin{array}{l}\text { Accepted } \\
\mathrm{H}_{0}\end{array}$ \\
\hline $\begin{array}{l}\text { H26: There is no significance relationship between Career Advancement Opportunities \& Reward \& } \\
\text { Recognition. }\end{array}$ & 0.896 & 1.64 & $90 \%$ & $\begin{array}{c}\text { Accepted } \\
\mathrm{H}_{0}\end{array}$ \\
\hline $\begin{array}{l}\text { H27: There is no significance relationship between Career Advancement Opportunities and Open Envi- } \\
\text { ronment. }\end{array}$ & 0.821 & 1.64 & $90 \%$ & $\begin{array}{c}\text { Accepted } \\
\mathrm{H}_{0}\end{array}$ \\
\hline $\begin{array}{l}\text { H28: There is no significance relationship between Career Advancement opportunities and Employee } \\
\text { Empowerment }\end{array}$ & 0.996 & 1.64 & $90 \%$ & $\begin{array}{l}\text { Accepted } \\
\mathrm{H}_{0}\end{array}$ \\
\hline $\begin{array}{l}\text { H29: There is no significance relationship between Career Advancement Opportunities and Service \& } \\
\text { Support }\end{array}$ & 0.38 & 1.64 & $90 \%$ & $\begin{array}{l}\text { Accepted } \\
\mathrm{H}_{0}\end{array}$ \\
\hline $\begin{array}{l}\text { H30: There is no significance relationship between Career Advancement Opportunities and Job Charac- } \\
\text { teristics. }\end{array}$ & $-\overline{186}$ & 1.64 & $90 \%$ & $\begin{array}{c}\text { Accepted } \\
\mathrm{H}_{0} \\
\end{array}$ \\
\hline
\end{tabular}

Employees are unique individuals having their own mind set and they should be treated accordingly, the identified EBD in the present research includes Reward and recognition, Open Environment, Employee Engagement, Service and support, Job Characteristics and career advancement opportunities. With four generations in the workplace and a wide variance in employee motivations specially in IT sector will help companies to develop suitable and optimal EBD strategies in order to gain the operative superiority.

\section{Acknowledgement}

I extend my sincere thanks to the employees of selected Information Technology (IT) companies for their valuable inputs during the process of data collection. 


\section{References}

[1] Johnson M \& Roberts P (2006), "Rules of attraction: Recruit and retain the best staff with employer branding", Marketing Health Services, Vol. 26, No. 1, pp. 38-40.

[2] Dyar (2007), "Employer branding: A vital tool for success", Strategic Communication Management, Vol. 2, No. 1, pp. 2.

[3] Bryan LL \& Joyes CI (2007), Mobilizing Minds: Creating wealth from talent in the 21st century organisation: McGraw Hill, New York

[4] Ambler T \& Barrow S (1996), "The employer brand" The Journal of Brand Management, Vol. 4, No. 3, pp. 85-106.

[5] Backhaus K \& Tikoo S (2004), "Conceptualizing and researching employer branding", Career Development International, Vol. 9, No. 5, pp. 501-17.

[6] Frook J.E (2001), "Burnish Your Brand from Inside”, Vol. 86, B to B, pp. 1-2.

[7] Rachael Maxwell \& Simon Knox (2006), "Motivating employers to "live the brand": a comparative case study of employer brand attractiveness within the firm". Journal of Marketing Management, Vol. 25, No. 9-10, pp.893-907.

[8] Linda F Love \& Parbudayal Singh (2011), "Workplace Branding. Leveraging Human Resources Management Practices for Competitive Advantage Through" Best Employer Surveys, Springer Journal of Business Psychology, Vol. 26, pp. 175-181.

[9] Pushpendra Priyadarshi (2001), "Employer brand image as a predicator of employer satisfaction, affective commitment and turnover", The Indian Journal of Industrial Relation, Vol. 46. No.3.

[10] Knox S \& Frerman C (2006), "Measuring and managing employer brand image in the service industry" Journal of Marketing Management, Vol. 22, pp. 695-716.

[11] Aln Robertson \& Ali Khatibi (2012), "By design or by default: Creating the employer indentity", IUP Journal of Brand Management, Vol. 9, No.4

[12] Kanika Sehgal \& N Malati (2013), Employer branding: A potent organisational tool for enhancing competitive advantage", IUP Journal of Brand Management, Vol. 10, pp. 51-56.

[13] Neha Sharma \& Kamalanabhan TJ (2014), "IT employees brand attributes and the role of internal corporate communication: a survey of Indian IT industry", International journal of business excellence, Vol. 7, No. 1, pp. 55-75.

[14] Janse Van Rensburg A \& Roott G (2009), "Evaluating a methodology for assessing the strategic alignment of a mining company recruitment function", SA Journal of Human Resource Management, Vol. 7, pp. 1-201

[15] Neeti Leetha Chhabra and Aparna Misra (2008), "The Icfaian", Journal of Management Research, Vol. 7. No. 11.

[16] Nor Adibah Ahmada \& Salina Daud (2016), "Engaging People with Employer Branding" Procedia Economics and Finance, Elseveir Publication, pp. $690-698$ 